\title{
Penile cancers without the AIDS epidemic in Cameroon
}

\author{
Blaise Nkegoum \\ From 13th International Conference on Malignancies in AIDS and Other Acquired Immunodeficiencies \\ (ICMAOI) \\ Bethesda, MD, USA. 7-8 November 2011
}

\section{Background}

Cancer of the penis is an uncommon malignancy in developed countries, But the incidence is as high as $17 \%$ of all male cancers in some undeveloped countries. The most important aetiologic factor is the presence of an intact foreskin but this is still unknown.

Cameroon is a blank area on the world cancer map because medical facilities necessary for recording cancer cases and the population data necessary for the calculation of rate are scarce or inexistent. Only $10 \%$ of malignant neoplasms are confirmed by histology.

\section{Methods}

We described the pathological aspects of 10 cases of penile cancers observed in Cameroon, a developing country of 20.000.000 inhabitants, within a period of twenty seven years (1984-2011). Human Immunodeficient Virus (HIV) serology test was done for nine patients of this series. Human Papilloma Virus (HPV) DNA detection and typing were carried out on paraffin-embedded specimens of our cases by Polymerase Chain Reaction.

\section{Results}

The patients aged 43 to 75 years and were circumcised. Four of the ten cases were diagnosed in 2004. HIV serology test done on 3 cases before 2004 were negative. After 2004, six patients were registered and out of these six, three came down with HIV-AIDS.

One patient has type II diabetes mellitus. All patients consulted late with metastatic disease. The pathological type was squamous cell carcinoma for nine patients while one other has a Diffuse large B cell lymphoma. HPV DNA was detected in six cases.

Correspondence: nkegoum@yahoo.fr

University Hospital Center, Yaounde, Cameroon

\section{Conclusion}

Ten cases of penile cancer were observed in Cameroon within the AIDS epidemic. These are cases which are confirmed by histology as only $10 \%$ of the patients with cancer can have histology performed. The aetiology is unclear. The HIV should be investigated as an etiologic factor.

Published: 19 April 2012

doi:10.1186/1750-9378-7-S1-P19

Cite this article as: Nkegoum: Penile cancers without the AIDS epidemic in Cameroon. Infectious Agents and Cancer 2012 7(Suppl 1):P19.

\section{Submit your next manuscript to BioMed Central and take full advantage of: \\ - Convenient online submission \\ - Thorough peer review \\ - No space constraints or color figure charges \\ - Immediate publication on acceptance \\ - Inclusion in PubMed, CAS, Scopus and Google Scholar \\ - Research which is freely available for redistribution

